\title{
PENGUATAN POLA ASUH TERHADAP TUMBUH KEMBANG ANAK USIA DINI DALAM KELUARGA MELALUI PEMBERDAYAAN MASYARAKAT DI DESA PETAK BAHANDANG
}

\author{
Ridha Nirmalasari'1), Ahmad Aldianor ${ }^{2)}$, Ervianie Putri Asfari3), Raju Anand ${ }^{4)}$, Rini Septiani ${ }^{1)}$, \\ Siti Nurhalisa ${ }^{5)}$
}

\author{
1)Tadris Biologi, FTIK, Institut Agama Islam Negeri Palangka Raya, Kota Palangka Raya, Indonesia \\ 2)Pendidikan Agama Islam, FTIK, Institut Agama Islam Negeri Palangka Raya, Kota Palangka Raya, Indonesia \\ 3)Ekonomi Syariah, FEBI, Institut Agama Islam Negeri Palangka Raya, Kota Palangka Raya, Indonesia \\ 4)Tadis Bahasa Inggris, FTIK, Institut Agama Islam Negeri Palangka Raya, Kota Palangka Raya, Indonesia \\ ${ }^{5)}$ Bimbingan Konseling Islam, FUAD, Institut Agama Islam Negeri Palangka Raya, Kota Palangka Raya, Indonesia \\ Corresponding author : Ahmad Aldianor \\ Email : aldianorahmad@gmail.com
}

Diterima 29 September 2021, Direvisi 26 November 2021, Disetujui 26 November 2021

\begin{abstract}
ABSTRAK
Salah satu permasalahan yang ada di masyarakat Desa Petak Bahandang yaitu kurangnya pemahaman yang lebih mendalam mengenai pola asuh yang tepat dalam mengasuh anak.Sebagian besar pola asuh yang terdapat di desa Petak Bahandang ditemukan banyak orang tua yang salah menerapkan pola asuh kepada anak-anaknya. Mereka secara tidak sengaja telah melakukan kesalahan dalam pengasuhan mereka yang dapat berdampak negatif pada pertumbuhan dan perkembangan anak. Metode pengabdian ini adalah PAR (Participatory Action Research) yaitu pengabdian berbasis masalah yang ditemukan lalu kemudian memberikan alternative solusi yaitu penyuluhan yang berkaitan dengan pemahaman mengenai pola asuh di depan masyarakat Desa Petak Bahandang.Kegiatan pengabdian kepada masyarakat ini dilakukan di posyandu balita dengan sasaran ibu-ibu PKK yang berjumlah 13 peserta. Metode pelaksanaan yang diterapkan dmulai dari tahap persiapan, pelaksanaan, tahap evaluasi dan monitoring.Berdasarkan penelitian dan hasil observasi yang dilakukan di Desa Petak bahandang bahwa para orang tua telah menerapkan keempat pola asuh terhadap anak, baik itu pola asuh yang bersifat otoriter, permisif, cuek serta demokratis. Namun, kebanyakan dari orang tua di Desa Petak Bahandang menerapkan pola asuh otoriter. Diharapkan para orang tua khususnya masyarakat desa Petak Bahandang untuk terus meningkatkan pengetahuan dan pengalaman terkait dengan pola asuh yang baik untuk anak-anaknya.
\end{abstract}

Kata kunci: anak; pola asuh; orang tua.

\begin{abstract}
One of the problems in the community of Bahandang Village is the lack of a deeper understanding of proper parenting. Most of the parenting contained in the village of Bahandang Plot found many parents who wrongly apply parenting to their children. They have inadvertently made mistakes in their upbringing that can negatively impact a child's growth and development. This method of devotion is PAR (Participatory Action Research) which is a problem-based service that is found and then provides alternative solutions, namely counseling related to understanding parenting in front of the community of Bahandang Village. This community service activity is carried out in posyandu toddlers with the target of PKK mothers numbering 13 participant. The implementation methods applied start from the stage of preparation, implementation, evaluation and monitoring stages. Based on research and observations conducted in Petak Bahandang Village that parents have applied all four parenting to children, be it parenting that is authoritarian, permissive, indifferent and democratic. However, most of the parents in Bahandang Village apply authoritarian parenting. It is expected that parents, especially the people of Petak Bahandang village to continue to increase knowledge and experience related to good parenting for their children.
\end{abstract}

Keywords: child; parenting; parents.

\section{PENDAHULUAN}

Anak usia dini adalah anak yang

berada pada rentang usia 0 sampai 6 tahun dimana terjadi proses tumbuh kembang yang pesat sehingga memerlukan stimulasi yang baik untuk tumbuh kembangnya secara lebih maksimal. Jika anak-anak tersebut dapat berkembang dengan baik, maka mereka akan 
tumbuh dan berkembang dengan perilaku yang baik pula. Namun sebaliknya apabila terjadi hambatan dalam perberkembangan mereka maka berbagai masalah tingkah laku dan karakter akan timbul dalam diri anak tersebut (Fabiani \& Krisnani, 2020). Menjadikan anak yang baik dan berkualitas adalah suatu bentuk tanggung jawab menjadi orang tua. Anak merupakan suatu amanah yang diberikan oleh Allah SWT kepada orang tua yang harus dipertanggungjawabkan di akhirat kelak. Sebagian besar waktu anak dihabiskan di dalam lingkungan keluarga yang berperan sebagai sarana sosialisasi utama bagi anak. Orang tua memegang peranan penting dalam perkembangan fisik dan mental anak. Perhatian, kontrol dan tindakan orang tua merupakan salah satu bentuk pola asuh yang dapat memberikan dampak panjang terhadap kelangsungan perkembangan fisik dan mental anak. Pola asuh adalah suatu model perlakuan, sikap, atau tindakan orang tua dalam membina dan membimbing serta merawat anak sehingga mereka dapat berdiri sendiri (Anisah, 2011).

Pola asuh orang tua berdampak pada perkembangan kepribadian anak setelah dewasa (Sukamto \& Fauziah, 2021). Hal ini karena sifat dan unsur karakter individu dewasa sebenarnya jauh sebelum benih itu ditanamkan dalam jiwa individu sejak awal, yaitu ketika ia masih kecil. Artinya, cara orang tua memperlakukan anaknya sejak bayi akan mempengaruhi perkembangan sosial dan moralnya di masa dewasa. Perkembangan sosial dan moral ini akan membentuk karakter dan sikap anak di masa depan, meskipun ada beberapa faktor lain yang mempengaruhi pembentukan sikap anak yang tercermin dalam karakternya (Ayun, 2017). Penting bagi kita untuk memikirkan bentuk pola asuh apapun agar tidak buruk dalam merawat anak kita, pendidikan dini yang baik akan sangat menentukan masa depan mereka, jadi ini adalah sesuatu yang krusial yang sangat penting bagi kita dalam sosialisasi orang tua. Serta calon orang tua yang akan melakukan perjalanan dengan anak-anak mereka.

Secara teori, ada 3 jenis pola asuh yang dilakukan oleh orang tua, yaitu pola asuh otoriter, permisif, dan demokratis. Ketiga jenis pola asuh tersebut memiliki pengaruh yang besar terhadap perkembangan kepribadian anak, karena pola asuh orang tua sangat menentukan karakter, sikap dan perilaku anak di masa yang akan datang. Islam sendiri jelas memiliki aturan-aturan yang benar bagi perkembangan keluarga dalam hal ini, pengasuhan keluarga, dimulai dari pembinaan keluarga, interaksi antara ayah dan ibu, bagaimana peran ayah dilakukan oleh dua karakter yang berbeda yaitu, Ayah dan anak. Al-Qur'an dan Hadits sebagai sumber utama ajaran Islam telah menggambarkan aturan untuk berbagai interaksi dalam keluarga sebagai acuan untuk meningkatkan akhlak mulia (Anisah, 2011).

Salah satu permasalahan yang ada pada masyarakat desa Petak Bahandang adalah kurangnya pemahaman yang lebih mendalam tentang pola asuh yang benar dalam pola asuh. Sebagian besar pola asuh yang terdapat di desa Petak Bahandang ditemukan banyak orang tua yang salah menerapkan pola asuh kepada anak-anaknya. Bahkan, mereka secara tidak sengaja telah melakukan kesalahan dalam pengasuhan mereka yang dapat berdampak negatif pada pertumbuhan dan perkembangan anak. Berangkat dari permasalahan di atas, maka dilakukan kegiatan yang akan membantu tercapainya tujuan yaitu memberdayakan masyarakat Petak Bahandang dengan memperkuat pola asuh bagi tumbuh kembang anak usia dini. Dengan tidak dapat menangkap segala sesuatu yang berhubungan dengan baik dan buruk dengan tumbuh kembang anak usia dini, mereka aktif dan kuat dalam ingatan, tetapi mereka juga harus dengan setiap tindakan dan perlakuan yang mereka terima akan rapuh. Berbeda dengan anak-anak dari masa remaja hingga dewasa, mereka memiliki kontrol dan pemahaman yang cukup untuk beradaptasi dengan hal-hal yang diberikan kepada mereka.

\section{METODE}

Metode pengabdian ini adalah PAR (Participatory Action Research) yaitu pengabdian berbasis masalah yang ditemukan lalu kemudian memberikan alternative solusi yaitu penyuluhan yang berkaitan dengan pemahaman mengenai pola asuh di depan masyarakat Desa Petak Bahandang.

Kegiatan pengabdian kepada masyarakat ini dilakukan di posyandu balita dengan sasaran ibu-ibu PKK yang berjumlah 13 peserta. Metode pelaksanaan yang diterapkan dmulai dari tahap persiapan, pelaksanaan, tahap evaluasi dan monitoring.

Tahapan persiapan dilakukan dengan melakukan pendekatan kepada warga setempat, mengobservasi sistem pola asuh lingkungan setempat sesuai dengan topik yang akan diambil, lalu merencanakan waktu kegiatan, selanjutnya melakukan pendekatan kepada para tokoh yang terlibat dalam mengurus permohonan ijin kepada pihak terkait.

Tahapan pelaksanaan dilakukan dengan melakukan sosialisasi kepada ibu-ibu PKK mengenai Pentingnya Penerapan Pola 
Asuh Yang Baik Dalam Upaya Pencegahan Dampak Buruk Bagi Perkembangan dan Kepribadian Anak yang dilakukan dalam bentuk pemberian materi, tanya jawab dan diskusi interaktif.

Tahapan evaluasi pada program yang telah dilaksanakan meliputi telah terlaksananya Pentingnya Penerapan Pola Asuh Yang Baik Dalam Upaya Pencegahan Dampak Buruk Bagi Perkembangan dan Kepribadian Anak. Evaluasi dilakukan terhadap respon para ibuibu melalui tanya jawab dan diskusi terkait dengan materi penyuluhan.

Kegiatan ini dilakukan agar masyarakat dapat lebih memahami pola asuh yang baik dan menerapkannya dalam kehidupan sehari-hari dan akan berdampak negatif bagi anak jika pola asuh tersebut menyebabkan perilaku yang buruk. Penting bagi kita, sebagai orang tua atau calon orang tua, untuk terus memperhatikan metode pengasuhan yang dapat kita gunakan untuk memberikan pengajaran terbaik kepada anak-anak kita dan memperoleh hasil terbaik dari apa yang kita ajarkan kepada mereka.

Pola asuh yang baik harus mendukung perkembangan intelektual, sosial, dan psikologis yang sehat. Ketiga hal tersebut memegang peranan penting dalam membangun karakter anak sebagai orang dewasa. Dalam dunia psikologi terdapat empat jenis pola asuh yang masing-masing memiliki pengaruh yang berbeda terhadap karakter anak. Sebagian besar orang tua memilih pola asuh yang dominan dibandingkan pola asuh lainnya (Sari et al., 2020).

\section{HASIL, PEMBAHASAN, DAN DAMPAK Hasil}

\section{Pola Asuh Otoriter}

Wawancara yang dilakukan temanteman pada saat sosialisasi atau penyuluhan di Desa Petak Bahandang, Kecamatan Tasik Payawan, Katingan membuahkan hasil yang mengejutkan dengan penduduk desa yang mengatakan bahwa mereka lebih menyukai orang tua yang otoriter dalam membesarkan atau mendidik anaknya. Hal ini ditandai dengan banyaknya anak yang menyimpang atau melakukan banyak tindakan yang terlarang, seperti meminum alkohol, menggunakan obat-obatan terlarang, dan bersikap kasar atau kasar kepada orang lain. Hal ini disebabkan karena anak mendapatkan perlakuan yang kasar atau kurang menyenangkan dari orang tua mereka sejak dini, diusia mereka yang masih kecil mereka bisa mengingat dengan baik namun belum bisa menyaring hal baik dan buruk dengan benar, oleh karena itu tergantung dari perlakuan orang terdekat mereka terlebih lagi orang tua, mereka akan mengingat dan menirukannya. Anak-anak kurang bisa mengekspresikan dan mengungkapkan apa yang diinginkan ataupun apa yang mereka rasakan, anak lebih suka diam dan menutup diri. Orang tua yang melakukan pola asuh otoriter memiliki pikiran mereka akan memiliki anak yang bisa menurut kepada setiap perkataan orang tuanya, berharap memiliki anak yang juga bisa bersifat "tegas", orang tua yang melakukan pola asuh ini lebih senang melakukan keputusan sepihak yang mana anak tidak akan bisa melawan, dan orang tua juga tidak tahu pastinya apakah anak tersebut bisa dalam mengikuti setiap keinginan orang tuanya, jika anak tidak bisa mengikuti keinginan orang tuanya, anak mendapatkan punishment (Hukuman) atau mendapat kekerasan nonverbal dari orang tuanya.

\section{Pola Asuh Permisif}

Berdasarkan hasil wawancara yang dilakukan teman-teman saat melakukan sosialisasi atau penyuluhan tentang Pola Asuh Anak Usia Dini ini, mereka mendapatkan kenyataan bahwa beberapa dari orang tua menerapkan pola asuh permisif dimana mereka memanjakan anak-anak mereka sehingga anak-anak tersebut bergantung kepada orang tua dan apa yang mereka inginkan selalu dipenuhi, sehingga menyebabkan anak tersebut memiliki tingkat keegoisan yang tinggi dan cenderung tidak bisa melakukan hal hal lain tanpa bantuan orang tua maupun orang lain. Anak-anak yang di asuh dengan pola asuh ini pun juga akan lebih sulit untuk menyesuaikan diri pada lingkungan baru, dikarenakan pola asuh yang membuat mereka selalu bergantung pada orang tua, hingga mereka akan merasa sulit untuk bertahan ataupun beradaptasi pada lingkungan baru, anak-anak yang mendapatkan pola asuh ini mencedrung mudah mengekspresikan apa yang mereka rasakan, ini bagus tetapi terkadang menyebabkan anak-anak memiliki sifat yang menuntut, egois dan tidak mau mendengarkan orang lain. Apa yang mereka inginkan harus terwujud sehingga ketika tidak bisa terwujud anak tersebut akan marah dan memberontak juga cenderung menyalahkan orang lain dalam hal keinginannya yang tidak bisa terwujud tadi.

\section{Pola Asuh Cuek}

Menurut penelitian yang sudah dilakukan dengan wawancara kepada 
sejumlah warga yang mengikuti penyuluhan sosialisasi pola asuh anak, terdapat beberapa orang tua yang memang mengasuh anak mereka dengan cuek, mereka hanya memberikan apa yang anak mereka perlukan sebisa mereka kemudian mereka berpindah dan sibuk mengurus urusan lain yang tidak melibatkan anak mereka ataupun berhubungan dengan mereka. Pola asuh ini mereka gunakan dengan harapan anak mereka dapat bersifat mandiri lebih cepat, lebih unggul dari anak - anak lain karena bersifat dewasa terlebih dahulu serta dapat melakukan hal yang mereka inginkan lebih baik. Orang tua yang menggunakan pola asuh ini juga berharap agar anak mereka dapat mengikuti hal dilakukan oleh orang tua mereka, memberikan apa yang anak inginkan lalu membiarkan mereka (cuek), sebagian orang tua yang menggunakan pola asuh ini juga memberikan penjelasan jika apa yang mereka lakukan dalam mendidik anak mereka adalah hal terbaik yang dapat mereka lakukan, serta mereka juga berpendapat jika pola asuh cuek merupakan pola asuh yang terbaik dari jenis pola asuh yang lain, dikarenakan di tempat kami ber-KKN di sana dominan mata pencaharian yang bekerjanya memerlukan banyak waktu sehingga mereka tidak memiliki banyak waktu bersama anak mereka, namun mereka tetap dapat memberikan apa yang anak mereka mau sebagai gantinya.

\section{Pola Asuh Demokratis}

Hasil wawancara dengan warga $m$ desa saat melakukan penyuluhan dan sosialisasi tentang pola asuh anak, mendapatkan data yang menggunakan pola asuh anak demokratis namun tidak banyak yang melakukan pola asuh ini, orang tua yang melakukan pola asuh ini memiliki harapan agar anak tumbuh dan berkembang dengan baik, karena pola asuh ini memiliki banyak ikatan antara anak dan orang tua (Handaka et al., 2018). Orang tua yang kami wawancarai juga menyatakan mereka senang bisa dekat dan mendengarkan setiap hal yang dikatakan oleh anak, dan orang tua juga tetap bisa memberikan pelajaran dengan baik disamping mereka tetap memberikan pemahaman, teguran, bahkan mengkritik anak mereka ketika anak melakukan kesalahan, sebagian orang tua tidak mengetahui tentang pola asuh ini mereka melakukan apa yang bisa mereka lakukan agar kelak anak - anak mereka memiliki kepribadian yang baik, aktif di usia mereka serta mampu bersaing dengan anak lain. Anak juga memiliki sifat bertanggung jawab, mampu mengambil keputusan dengan baik dan mampu mengekspresikan pikiran dan perasaan mereka dengan baik.

\section{Pembahasan}

Banyaknya terdapat tindak pendidikan yang kurang pantas dari orang tua terhadap anaknya, terlebih kepada anak - anak yang masih memiliki rentang umur anak usia dini, mereka tidak mendapatkan perlakuan kasih sayang serta kelembutan dari orang tua mereka melainkan hanya perlakuan yang akan membuat mereka takut untuk belajar hal baru, tidak percaya diri, serta menyembunyikan tingkat intelektual mereka, karena diusia yang sangat muda mereka akan dengan mudah mengingat dan merekam setiap perlakuan yang mereka dapatkan, setelah kami menjadi tenaga pendidik bagi mereka yang masih berusia sangat muda, kami menemukan banyaknya kekurangan kecerdasan dalam pemikiran mereka, mereka terbiasa dengan perlakuan yang selama ini mereka dapatkan, tidak hanya masalah sopan santun, mereka juga sangat lemah dalam intelektual. Tidak sedikit dari mereka yang tidak bisa membaca, berhitung, serta mengetahui huruf sekalipun. Hal ini dikarenakan kebiasaan yang mereka dapatkan atau yang mereka lihat secara langsung. Di sini dapat kita lihat jika mereka sangatlah aktif dalam belajar, namun sayang mereka tidak mendapatkan perlakuan yang seharusnya mereka dapatkan.

Anak adalah peniru yang baik, mereka akan mereplikasi apapun yang mereka lihat, dengar, rasakan, dan alami (Yuniartiningtyas, 2013). Anak memerlukan perhatian khusus untuk mendukung dan mengoptimalisasi tumbuh kembangnya. Jika anak tumbuh di lingkungan yang memperlakukan mereka secara keras, maka anak akan memiliki kepribadian yang keras pula dan berkemungkinan untuk melakukan perilaku bullying.

Karena itulah kami di sini berusaha menguatkan pola asuh dalam keluarga, salah satunya dengan melakukan sosialisasi kepada warga desa, selain untuk memberikan kesadaran dan pengajaran kepada orang tua agar mereka dapat menerapkan atau mengimplikasikan kepada anak-anak mereka agar terciptanya pola asuh yang baik, kami juga bertujuan untuk membentuk keluarga yang harmonis untuk para warga desa, terlebih bagi 
mereka, orang tua yang ingin anak-anak mereka tumbuh menjadi orang yang hebat dan bisa membanggakan orang tua mereka.

Mewujudkan anak yang baik dan berkualitas merupakan sebuah tanggung jawab yang harus dipikul oleh orang tuanya. Allah memberikan anak sebagai amanah bagi orang tua yang kelak akan dipertanggung jawabkan nanti di akhirat. Karena itu orangtua wajib memelihara, membesarkan, merawat, menyantuni, dan mendidik anak-anaknya dengan penuh tanggung jawab dan rasa kasih sayang. Tanggung jawab orang tua terhadap anakanaknya merupakan tanggung jawab yang tidak mudah. Orang tua harus menjaga anak dan seluruh anggota keluarganya selamat dari siksa api neraka, hal ini dinyatakan dalam Al Qur'an Surat AlTahrim (66): ayat 6 (Padjrin, 2016). Dalam hadits pun sudah dijelaskan bahwa sudah menjadi kewajiban kita sebagai orang tua untuk menjaga titipan Tuhan kepada kita, yaitu karunia memiliki buah hati atau anak, dengan mempertahankan kehidupan mereka, mensejahterakan mereka dan mengajari mereka bagaimana mereka bisa menjadi anak yang baik kepada orang tua, berbakti dan memiliki pengetahuan mengenai agama mereka. Berdasarkan kutipan dalil di atas, membuat kami semakin yakin untuk membantu menyadarkan orang tua tentang pentingnya menyayangi dan mengajari anak-anak mereka.

Pentingnya pola asuh pada usia dini, memiliki arti bahwasannya anak usia dini merupakan usia mereka aktif, usia emas mereka dalam melakukan, merasa diri mereka bisa melakukan apapun yang mereka inginkan, bebas berfikir, berkreasi dan ingin selalu tahu. Namun, harus selalu ingat dengan semua itu mereka hanyalah anak kecil yang rapuh, yang tidak bisa sedikit melihat kejadian yang menyakitkan hati mereka, mereka akan sedih menangis dan terus mengingatnya. Semuanya bergantung dengan pola asuh orang tua mereka, jika mereka bisa memberikan asuhan yang baik dan positif kepada anakanak mereka maka akan adanya timbal balik pula, anak-anak akan mudah beradaptasi cepat menangkap, aktif dan memiliki kecerdasan yang baik. Namun beda halnya dengan anak yang mendapat asuhan yang buruk dan negatif, mereka akan cenderung murung, pendiam dan merasa tidak percaya diri untuk bermain bersama anak-anak lain bahkan mereka tidak bisa bergaul dengan baik dan menimbulkan masalah seperti berkelahi, membully ataupun terbully sekalipun.

Pola asuh yang baik harus dilakukan sedini mungkin demi menghindari sikap buruk dari anak-anak yang tertanam sejak mereka kecil dan mempengaruhi diusia pendewasaan merek. Kenapa sejak dini? Karena mereka belum bisa dengan benar membedakan yang mana bisa mereka tiru dan mana yang bisa mereka harus hindari, mereka bisa meniru namun belum bisa menyaring/memfilter apa yang mereka dapatkan.

Lingkup keluarga adalah suatu lembaga terkecil yang mempunyai peran yang strategis dalam pengupayaan hal penyadaran, penanaman dan pengembangan nilai yang dimana sebagai salah satu upaya pembentukan karakter anak. Melalui pola asuh orang tua, internalisasi nilai dapat berkembang melebihi jumlah dan intensitasnya yang diterapkan dari lingkungan sekolah, sehinggga kadar internalisasi nilai pada anak akan cenderung melekat pada diri anak dibanding yang di dapat di sekolah. Hal tersebut dapat terjadi dikarenakan kuatnya ikatan emosional yang dimiliki orang tua dan anak, oleh sebab itu wilayah pendidikan nilai dalam upaya pembentukan karakter harus sudah berlangsung sejak anak berada dalam kandungan sampai akhir hayatnya.

Keluarga adalah tempat awal bagi anak untuk menunjukkan bagaimana diri mereka kepada orang terdekat, maka dari itu keluarga memiliki pengaruh yang sangat besar untuk perkembangan anak itu sendiri, dengan memberi mereka pendidikan dan asuhan yang benar akan sangat membantu dalam mengembangkan diri mereka, oleh karena itu pendidikan anak tidak dapat dipisahkan dari keluarganya karena keluarga merupakan tempat pertama kali anak menyatakan diri sebagai mahkluk social dalam berinteraksi dengan kelompoknya (Mustakin 2013).

\section{Pola Asuh Otoriter}

Hasil dari sosialisasi diketahui bahwasanya banyak orang tua yang menggunakan pola asuh otoriter, hamper kebanyakan orang tua menggunakan pola asuh ini, mereka mengaku bahwa anak harus mendapatkan didikan dan bimbingan yang keras untuk mereka patuh dan tunduk terhadap setiap perintah dan perkataan dari orang tua mereka dan pola asuh ini bersifat turun-temurun. Pola asuh otoriter menjadikan anak menjadi tidak bebas 
dalam melakukan aktivitasnya, hal inilah yang dapat menyebabkan anak menjadi tidak percaya diri terhadap kemampuan yang dimilikinya (Adawiah, 2017).

Dapat kita lihat, pola asuh otoriter merupakan pola asuh yang sangat tegas dan keras, pola asuh ini jika diajarkan dengan cara yang benar dan tepat mungkin dapat meminimalisasikan efek yang diterima oleh anak terhadap perlakuan orang tua mereka. Pola asuh ini timbul dari orang tua yang bersifat egois dan hanya ingin mereka saja yang didengar oleh anak mereka tanpa mau mendengarkan apa yang diinginkan dan dirasakan oleh anak mereka, pola asuh ini juga menimbulkan anak bersifat berontak dank eras terhadap anak atau orang lain, karena diusia mereka itu tadi lah mereka akan meniru kebiasan buruk orang tua mereka dan bahkan mereka bisa melakukannya hal yang lebih buruk. Mereka akan terbiasa bersifat keras sehingga ketika berbaur mereka akan cenderung menerapkan itu dan hal tersebut merupakan hal yang tidak baik di usia mereka, terlebih lagi mereka akan memiliki keterlambatan dalam hal intelegensi,lebih memilih pergaulan yang buruk dan terlalu bebas, jika sudah masuk dalam efek yang terburuk, mereka akan melakukan tindakan perlawanan dengan orang tua mereka, orang tua yang menjadi contoh bagi anak itu sendiri untuk berlaku layaknya orang tua mereka. Solusi yang dapat dilakukan adalah dengan memberikan pemahaman kepada anak, memberikan ruang untuk mereka mengeluarkan pemikiran mereka, memberikan mereka kebebasan saat mereka ingin mengekpresikan diri mereka, mulaillah dari hal yang paling sederhana sehingga anak tidak lagi merasa tertekan, menjadi beban dan memiliki sifat terbuka.

Solusi untuk pola asuh ini adalah dengan mengadakan atau memberikan pemahaman bahwa saat kita menjadi orang tua, kita sangat tidak diianjurkan melakukan kekerasan baik secara fisik maupun secara mental kepada anak, baik verbal maupun non-verbal, kita adalah orang tua dengan sejuta pemikiran yang sangat mungkin anak kita akan meniru setiap perbuatan, perkataan yang kita lakukan kepada orang lain ataupun kepada anaknya sendiri. Jika kita mengajarkan mereka dengan lemah lembut dan menyeimbangkan sikap kita, niscaya anak akan menerimanya dengan baik, karena bagaimapun orang tua adalah cerminan anak, bagaimana mereka bersikap dan berperilaku, jika kita kasar, mereka akan kasar dengan orang lain, bahkan hingga mereka memiliki anak mereka akan tetap bisa memberi kesan otoriter ke anak-anak mereka. Berbeda jika kita memberikan anak kita perlakuan lemah lembut namun tetap seimbang agar mereka tidak manja dan egois, mereka pasti dengan mudah beradaptasi dan memiliki pemikiran jika mereka adalah anak yang selalu dipikirkan dan dibesarkan dengan baik oleh orang tua mereka. Anak-anak yang baik dan hebat tercipta dari pola asuh orang tua yang benar, serta anak-anak yang memiliki semangat saat mereka dalam keadaan terendah untuk terus bangkit dan membanggakan orang tua mereka, solusi untuk tiap permasalahan akan selalu ada.

\section{Pola Asuh Permisif}

Hasil yang menunjukkan adanya beberapa orang tua yang menggunakan pola asuh ini. Pola asuh ini merupakan pola asuh yang bersifat memanjakan anak dengan memenuhi semua keinginan anak tanpa memberikan batasan kepada anak.

Pola asuh ini memiliki kelebihan dalam hal anak lebih bisa mengekspresikan diri, bisa menunjukkan keaktifan dan keceriaan mereka dalam bergaul dengan anak seusia mereka, namun pola asuh ini juga memiliki kekurangan di mana anak cenderung bersifat egois, keras kepala, tidak bisa berbaur di tempat baru, suka menuntut apa yang diinginkan harus terpenuhi, dan jika apa yang diinginkan tidak terpenuhi mereka cenderung menyalahkan orang lain. Beberapa hal yang memang dapat terjadi ketika orang tua menerapkan pola asuh permisif, anak bisa menjadi lebih ketergantungan bersama orang tua mengakibatkan mereka tidak bisa berkembang di lingkungan baru.

Menurut Dariyo (Anisa, 2005) Perilaku kurang disiplin anak terhadap aturanaturan yang berlaku merupakan akibat dari pola asuh yang permisif. Namun sebaliknya, jika anak mampu bertanggung jawab atas kebebasan yang ia daptkan, maka ia dapt menjadi seorang yang anak yang mandri, kreatif dan mampu mewujudkan aktualitasnya (Adawiah, 2017)

Solusi untuk pola asuh ini adalah dengan memberi anak batasan-batasan dan pengertian sehingga anak tidak memiliki ketergantungan yang besar kepada orang tua mereka, dan orang tua juga dituntut agar sedikit memberi ketegasan dalam mengajar dan mendidik anak mereka agar mereka tidak cenderung bersifat egois dan menuntut. Anak yang manja dapat menumbuhkan sikap angkuh 
yang berlebihan jika terus dibiarkan, maka dari itu pembatasan yang penting juga diperlukan namun jangan sampai batasan itu menjadi penghalang bagi anak untuk tumbuh dan berkembang.

\section{Pola Asuh Cuek}

Hasil dari penyuluhan menunjukkan tidak sedikit dari orang tua di sana menggunakan pola asuh cuek, berdasarkan penjelasan mengenai pola asuh cuek, di sini menunjukkan bahwa anak akan kekurangan kasih sayang dari orang tuanya, meskipun semua keperluan mereka terpenuhi namun mereka tetap kekurangan kasih sayang dan perhatian kedua orang tua mereka. Pola asuh ini juga menjadi pola asuh yang menjadi pilihan di sana, meskipun demikian pola asuh ini tetap saja masih memiliki banyak kekurangan dan mampu memberikan anak banyak celah untuk mereka berbuat sesuatu yang mana orang tua mereka tidak tahu atau menyadari akan perbuatan anak mereka sendiri, dari pola asuh yang memiliki banyak ruang, menimbulkan anak berperilaku terlalu bebas dan bukannya menjadi pribadi yang dewasa ataupun mandiri yang mana hal ini menimbulkan banyak masalah bagi anak, membuat mereka memiliki pemikiran yang bisa memberontak kepada orang tua, karena kurangnya perhatian orang tua dan menimbulkan anak memiliki pemikiran bebas sendiri, dan hal itu belum tentu baik untuk diri anak.

Solusi untuk pola asuh ini adalah dengan memberikan pemikiran kepada orang tua agar mereka bisa mengetahui apa saja yang diperlukan anak selain memenuhi kebutuhannya anak juga memerlukan quality time bersama orang tua, hal ini diperlukan untuk memberikan pola asuh yang seimbang kepada anak agar mereka bisa lebih memahami setiap maksud dan tindakan orang tua yang kenapa memberikan mereka perlakuan cuek. Sebenarnya dalam pola asuh anak ini baik dalam membantu anak untuk berkembang sendiri dan mampu memandirikan mereka lebih cepat asalkan dengan bimbingan dan ajaran yang tepat. Kita tidak selalu bisa mengandalkan sikap cuek jika anak kita tidak memiliki pemikiran terbuka ditambah lagi mereka masih anak kecil dengan pemikiran yang sangat sempit, mereka juga akan berpikir orang tua mereka tidak menyayangi mereka sebagaimana peran orang tua pada umumnya yang memberi anak mereka perhatian lebih dan kasih sayang yang besar sehingga anak akan cenderung ceria dan bahagia, namun tidak salah saat kita memberi sikap cuek ketika anak kita melakukan kesalahan yang berulang kali sehingga hal tersebut menjadi kebiasaan buruk bagi mereka ke depannya, inillah pentingnya bagi orang tua untuk terus memberikan pola asuh terbaik yang bisa mereka berikan kepada anak - anak mereka, yang akan menjadi generasi penerus bangsa.

\section{Pola Asuh Demokrasi}

Hasil dari sosialisasi ini kami mendapatkan sedikit dari sekian banyak orang tua di sana yang menerapkan pola asuh demokrasi, pola asuh yang sejauh ini menjadi pola asuh dengan hasil yang sangat baik, di mana pola asuh ini merupakan gabungan dari beberapa pola asuh yaitu pola asuh otoriter dan permisif.

Hanya ada sebagian orang tua yang memiliki pemikiran agar mereka bisa memberikan hal yang seimbang kepada anak mereka tidak terlalu kaku dan tidak terlalu bebas, jika kita lihat dari pola asuh yang terlalu memanjakan hingga terlalu kaku itu akan memberikan efek di mana anak terlalu bebas dan anak terlalu tertutup. Dengan pola asuh demokrasi anak tetap bisa mengekpresikan diri tetapi mereka tetap dalam batasan serta mereka dapat mempertanggung jawabkan hal yang mereka putuskan dengan benar. Maka dari itulah bisa dianggap pola asuh demokrasi merupakan pola asuh yang paling terbaik di antara pola asuh yang lain, sayangnya tidak banyak yang mengetahuinya di daerah desa-desa kecil, mereka masih kental dengan adat setempat serta budaya-budaya yang mengajarkan untuk memandirikan anak mereka secepat mungkin dengan harapan anak akan menjadi lebih dewasa dan bisa menjadi orang yang diharapkan oleh orang tua mereka. Salah satu pendekatan yang paling bisa digunakan untuk lebih cepat memandirikan anak adalah dengan menggunakan pola asuh demokrasi.

Solusi untuk orang tua terkait pola asuh demokrasi yang masih sedikit diterapkan orang tua warga desa petak bahandang terhadap anak-anak mereka adalah dengan memberikan saran bahwasannya anak adalah hal yang berharga mereka memiliki hati dan perasaan masingmasing, ada anak yang kuat dan mampu dalam menerima perlakuan keras orang tua mereka dan adapula anak yang tidak bisa sedikit pun mendapat perlakuan keras, maka dari itu pentingnya kita 
memberikan mereka kesadaran bahwa diri anak itu special dan berharga namun dibalik itu semua mereka tetaplah anak dengan semua kerapuhan dalam diri mereka. Jadi pelajaran yang dapat diberikan kepada orang tua adalah meletakkan kesadaran penuh dan perhatian yang seimbang kepada anak, agar anak dapat tumbuh dan berkembang dengan pembawaan dari orang tua yang baik.

Melalui kegiatan sosialisasi yang telah dilakukan oleh mahasiswa KKN ini dapat lebih mampu menyadarkan masyarakat terutama para orang tua yang berada di Desa Petak Bahandang. Hal ini dibuktikan dengan pengakuan dari beberapa masyarakat bahwa sebelum dilakukannya kegiatan sosialisasi terkait pola asuh anak ini mereka belum memahami sepenuhnya cara mengasuh anak yang baik dan benar, namun setelah dilaksanakannya kegiatan sosialisasi masyarakat menjadi lebih sadar dan paham akan pentingnya menerapkan pola asuh yang benar bagi tumbuh kembang anak (Sari et al., 2020).

Gambar kegiatan mahasiswa KKN dan masyarakat dalam sosialisasi pola asuh anak tersaji pada gambar 1 .

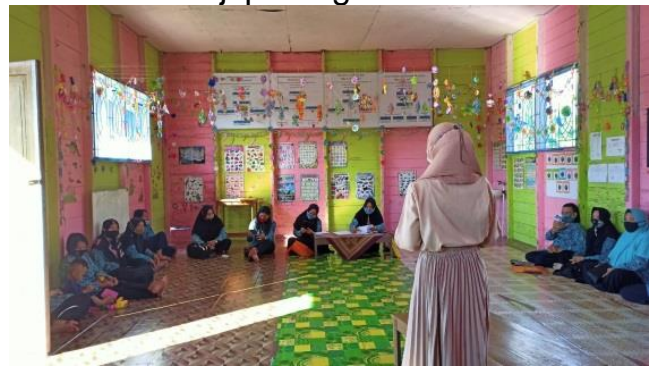

Gambar 1. Sosialisasi Pola Asuh Anak

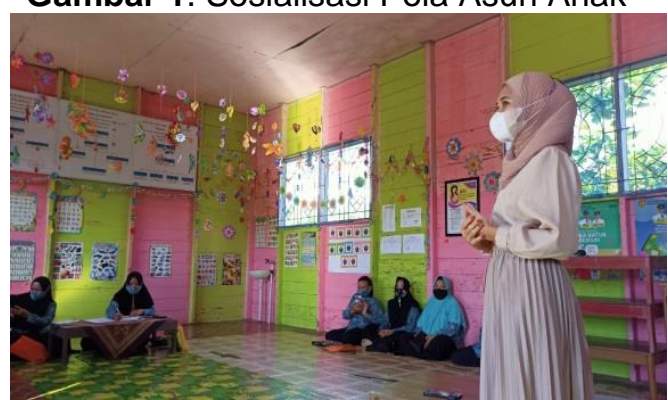

Gambar 2. Sosialisasi Pola Asuh Anak

\section{SIMPULAN DAN SARAN}

Penyuluhan mengenai pentingnya penerapan pola asuh yang baik dalam upaya pencegahan dampak buruk bagi perkembangan dan kepribadian anak terlihat dari meningkatnya pengetahuan dan pemahaman para orang tua di Desa Petak Bahandang. Hal itu terlihat dengan meningkatnya pengetahuan orang tua yang kurang baik (65\%) menjadi mempunyai pengetahuan yang baik (90\%) setelah dilakukannya penyuluhan mengenai pola asuh.

Penerapan pola asuh yang buruk dapat memberikan dampak negatif terhadap perkembangan dan kepribadian anak. Oleh karena itu, diharapkan dengan diadakannya penyuluhan mengenai pola asuh terhadap masyarakat, khususnya para orang tua dapat lebih menyadari terhadap penerapan pola asuh yang baik terhadap tumbuh kembang anak.

Seorang anak adalah investasi masa depan bagi setiap orang tua. Jika anak tersebut baik, maka investasi orang tua tentunya akan menjadi baik pula di masa depan. Maka dari itu, penting kiranya orang tua untuk memberikan pola asuh yang ideal untuk tumbuh kembang anak-anaknya. Para orang tua perlu untuk mengerti dan memahami mengenai apa yang menjadi kemauan dari buah hatinya, hal ini dilakukan agar terciptanya hubungan yang harmonis didalam keluarga. Diharapkan, dengan hubungan keluarga yang harmonis tentu akan menjadikan seorang anak memiliki berkepribadian yang baik, bahagia, dan menjadi kebanggaan bagi keluarga.

\section{UCAPAN TERIMAKASIH}

Pengabdi mengucapkan terimakasih kepada Kepala Desa, Ibu-lbu PKK, dan seluruh warga Desa Petak Bahandang, Kec. Tasik Payawan, Kab. Katingan yang telah bersedia menjadi subjek dalam pengabdian kepada masyarakat ini. Tidak lupa pula pengabdi mengucapkan terimakasih kepada IAIN Palangka Raya serta rekan-rekan pengabdi yang telah terlibat dalam kegiatan pengabdian masyarakat ini.

\section{DAFTAR RUJUKAN}

Adawiah, R. (2017). Pola Asuh Orang Tua dan Implikasinya Terhadap Pendidikan Anak (Studi pada Masyarakat Dayak di Kecamatan Halong Kabupaten Balangan). 7, 16.

Anisa, S. (2005). Kontribusi Pola Asuh Orang Tua Terhadap Kemandirian Siswa Kelas II SMA Negeri 1 Balapulang Kabupaten Tegal Tahun Pelajaran 2004/2005.

Anisah, A. S. (2011). Pola Asuh Orang Tua dan Implikasinya Terhadap Pembentukan Karakter Anak. 05, 15.

Ayun, Q. (2017). Pola Asuh Orang Tua dan Metode Pengasuhan Dalam Membentuk Kepribadian Anak. 5, 21.

Fabiani, R. R. M., \& Krisnani, H. (2020). Pentingnya Peran Orang Tua dalam 
Membangun Kepercayaan Diri Seorang Anak dari Úsia Dini. 7, 8.

Handaka, I. B., Hikmy, B. J., \& Musawwamah, A. (2018). Pemberdayaan Masyarakat Melalui Penguatan Pola Asuh Orangtua Terhadap Tumbuh Kembang Anak Dalam Pandangan Islam. 2, 6.

Padjrin. (2016). Pola Asuh Anak dalam Perspektif Pendidikan Islam. 5, 14.

Sari, D. A. W., Nurani, I. A., Damayanti, L., Ramadhan, M. B., \& lqbal, M. (2020). Optimalisasi Perilaku Hidup Bersih dan Sehat (PHBS) Guna Meningkatkan Kesejahteraan Masyarakat Desa Bawu Kecamatan Batealit Kabupaten Jepara Jawa Tengah. 18.

Sukamto, R. N., \& Fauziah, P. (2021). Identifikasi Pola Asuh Orangtua Di Kota Pontianak. 5, 8.

Yuniartiningtyas, F. (2013). Hubungan Antara Pola Asuh Orang Tua dan Tipe Kepribadian dengan Perilaku Bullying di Sekolah pada Siswa SMP. 